\title{
Lancelot Brown and the Notion of the Landscape Garden in the Netherlands: Illustrated with Het Loo Palace
}

\author{
Jan Woudstra and Willem Zieleman
}

Lancelot Brown produced designs for country seats in Germany and the Southern Netherlands (present-day Belgium), but there are no such examples in the Northern Netherlands (now the Kingdom of the Netherlands). He appears to have been little known there during his lifetime, with no obvious literary references to him in Dutch publications. Even when his landscapes were visited by Dutch travellers to England there was no reference to Brown. It was not until after the publication of Humphry Repton's Sketches and Hints on Landscape Gardening (1794) and Observations on the Theory and Practice of Landscape Gardening (1803) that both Brown and his work became better known and the term 'landscape garden' was popularised. The latter was not a new phrase; it had first been used by the poet William Shenstone (1714-63), as published posthumously in his 'Unconnected thoughts on gardening' (1764) where Brown's style was referred to as 'landskip, or Picturesque-gardening. The term had not seen general use, however, with Brown himself preferring 'place-making' to describe his work. ${ }^{1}$

During the nineteenth century Brown gradually gained a reputation in the Netherlands as one of the originators of the 'English landscape garden', which developed from what was referred to as the 'Engelse tuin', 'englische Garten', 'jardin anglais', or 'jardin anglo-chinois'. Despite supposed Englishness, these styles were distinct from what was happening in England at the time and had their roots in developments that had commenced in the formal garden. This nuance was not recognised by later observers and standard Dutch historiography has generally used the term 'early landscape style' to distinguish eighteenth-century irregular gardens from the later more Brownian-type open parks. ${ }^{2}$ A recent study of the development during the eighteenth century, however, recognises this misnomer and reclassifies eighteenth-century irregular gardens as the Dutch landscape style, suggesting a distinguishable development. ${ }^{3}$ Despite its clarity over how concepts evolved in the Netherlands, this study continues the avant la lettre use of the term 'landscape garden', and thereby perpetuates the confusion with the Brownian parks. In order to explain this, it is necessary to reassess the concepts from which the new

\footnotetext{
1 Stroud, D. (1950). Capability Brown (pp. 156-157).

2 Oldenburger- Ebbers, C. S., Backer, A. M. \& Blok, E. (1995). Gids voor de Nederlandse Tuin- en Landschapsarchitectuur (pp. 37, 42 determines the early landscape style (c. 1750-c. 1815) and the late landscape style (c. 1815-70)). Rotterdam: De Hef.

3 Tromp, H. M. J. (2012). De Nederlandse Landschapsstijl in de Achttiende Eeuw. Leiden: Sidestone Press.
}

How to cite this book chapter:

Woudstra, J. and Zieleman, W. 2020. Lancelot Brown and the Notion of the Landscape Garden in the Netherlands: Illustrated with Het Loo Palace. In Finch, J. and Woudstra, J. (Eds.), Capability Brown, Royal Gardener: The business of place-making in Northern Europe, pp. 165-180. York: White Rose University Press. DOI: https://doi.org/10.22599/CapabilityBrown.l. CC BY-NC 4.0 
developments arose within England. Others, conscious of the problems of distinguishing garden styles with national adjectives, have used the contemporary notion of the 'Picturesque garden." ${ }^{4}$ This chapter explores changing notions of English influences in the Netherlands, illustrated through the development of the design for one garden: the royal gardens of Het Loo Palace, Apeldoorn. The medieval castle of Het Loo had been acquired by William III in 1684, who built a new palace alongside it on a north-south orientation, with extensive formal gardens and groves. From the eighteenth to the twentieth century these gardens were continuously improved to conform with the latest trends.

\section{English Groves and Picturesque Gardens}

By the time Brown was born in 1716 there were a number of horticultural and design developments that were to determine the face of the parks and pleasure grounds in England during the later eighteenth century, which included experimentation in the planting of shrubs and a desire for more open arrangements by designers such as Charles Bridgeman, Stephen Switzer, and William Kent. ${ }^{5}$ By the early-eighteenth century the wildernesses and groves of the formal garden were criticised for the dense planting, with often 'four times' the number of trees required, which led to elongated plants, with 'taper stems' and 'scarcely any heads. ${ }^{6}$ An alternative manner of planting had been explored by Henry Wise at Kensington Palace in 1704, with shrubs and trees planted with wider spacings in a graduated manner, arranged according to height, creating the shape of a mound. ${ }^{7}$ Such planting soon caught on and was incorporated in designs for groves, alongside planting that observed 'regular irregularity' where no three trees were planted in the same line, but 'in a rural Manner, as if they had receiv'd their Situation from Nature itself.' This coincided with the introduction of serpentine paths. On the Continent, including the Netherlands, these principles were reiterated in Philip Miller's The Gardener's Dictionary (London, 1731), which was first translated into Dutch in 1745. Wildernesses were translated as 'Wild-bosschen' (wild woods), while the term 'Engelsch Bosch' (English woods/groves) was being used soon after, as was 'bosquet a l'angloise, 'Engelsch werk', 'Engelsche aanleg', and also 'slingerbosch' or 'slingerbosquet' (serpentine wood).'

Het Loo demonstrates how these new ideas of English groves were incorporated as part of incremental change within existing compartments of the garden. The royal gardens next to the new palace had been completed by 1690 for Stadholder William III and his wife Mary. They incorporated what, after their enthronement in England, became the king's wilderness or grove to the west and a smaller wilderness to the east of the walled gardens, which were primarily dedicated to different types of parterres. Beyond the king's wilderness was the old castle, surrounded by a moat, supplied by serpentine streams and an informal fish pond nearby, as shown in a 1699 survey drawn by Claude Desgotz (Figure 12.1). ${ }^{10}$ A proposal for the main garden area was made by Pieter de Swart (1709-73), who after his studies with Jacques-François Blondel from 1745 to 1747 was appointed as court architect for Stadholder William IV, sharing the post with an ageing Daniel Marot. De Swart's design for Het Loo, c. 1748, replaced some of the parterres a langloise within the walled area with further groves, with a new such area incorporating serpentine walks immediately to the north. The path layout of the king's wilderness was proposed to be altered also, with serpentine walks, clearly after the English manner (Figure 12.2).

While these designs do not appear to have been implemented, probably through the untimely death of Stadholder William IV in 1751, they do reveal a general desire for such innovations which from the mid-1760s

\footnotetext{
${ }^{4}$ Wiebenson, D. (1978). The picturesque garden in France. Princeton: Princeton University Press; Hunt, J. D. (2004). The picturesque garden in Europe. London: Thames and Hudson.

${ }^{5}$ Woudstra, J. (2013). From bosquet a l'angloise to jardin a l'angloise; the progression of the mingled manner of planting from its inception to its decline and survival. Studies in the History of Gardens \& Designed Landscapes 33 (2), 71-95.

${ }^{6}$ Miller, P. (1731). The gardeners' dictionary. London; under 'Wildernesses'.

7 Switzer, S. (1718). Ichnographia Rustica (Vol. 1, p. 83). London.

${ }^{8}$ Langley, B. (1728). New principles of gardening (pp. 186, 202). London.

9 Tromp, H. M. J. (2012). De Nederlandse Landschapsstijl (p. 38).

${ }^{10}$ Harris, W. (1699). A description of the King's royal palace and gardens at Loo (p. 38). London.
}

Figure 12.1 (page 167): Schematic survey of the layout of the gardens at Het Loo Palace, Claude Desgotz, 1699, with the formal walled gardens with parterres, the queen's wilderness to the right and the king's wilderness to the left; beyond this the old castle with irregular grounds. Source: Hårleman-Tessin Collection, Riksarkivet, Stockholm. Photo: Erik Cornelius / Nationalmuseum. CC BY-SA 4.0. 


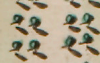

술

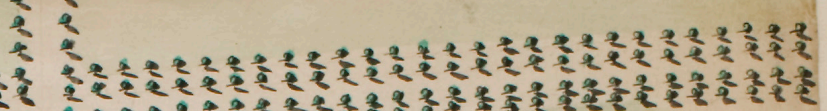

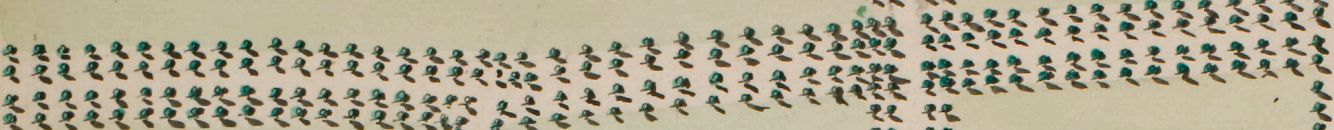

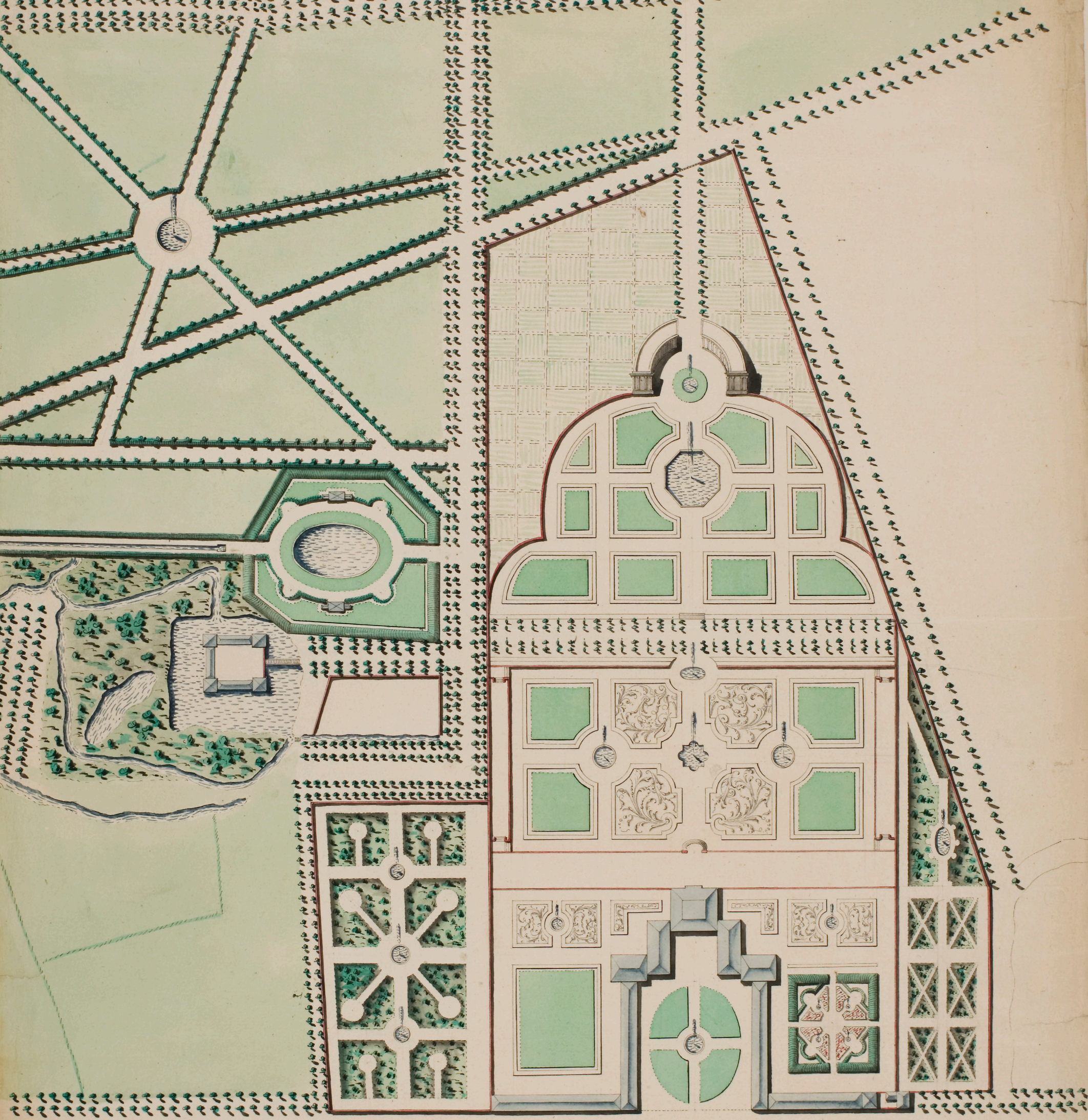

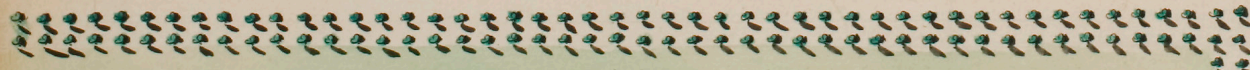

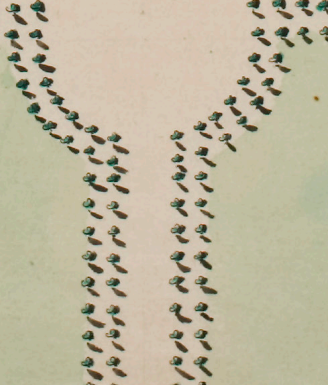




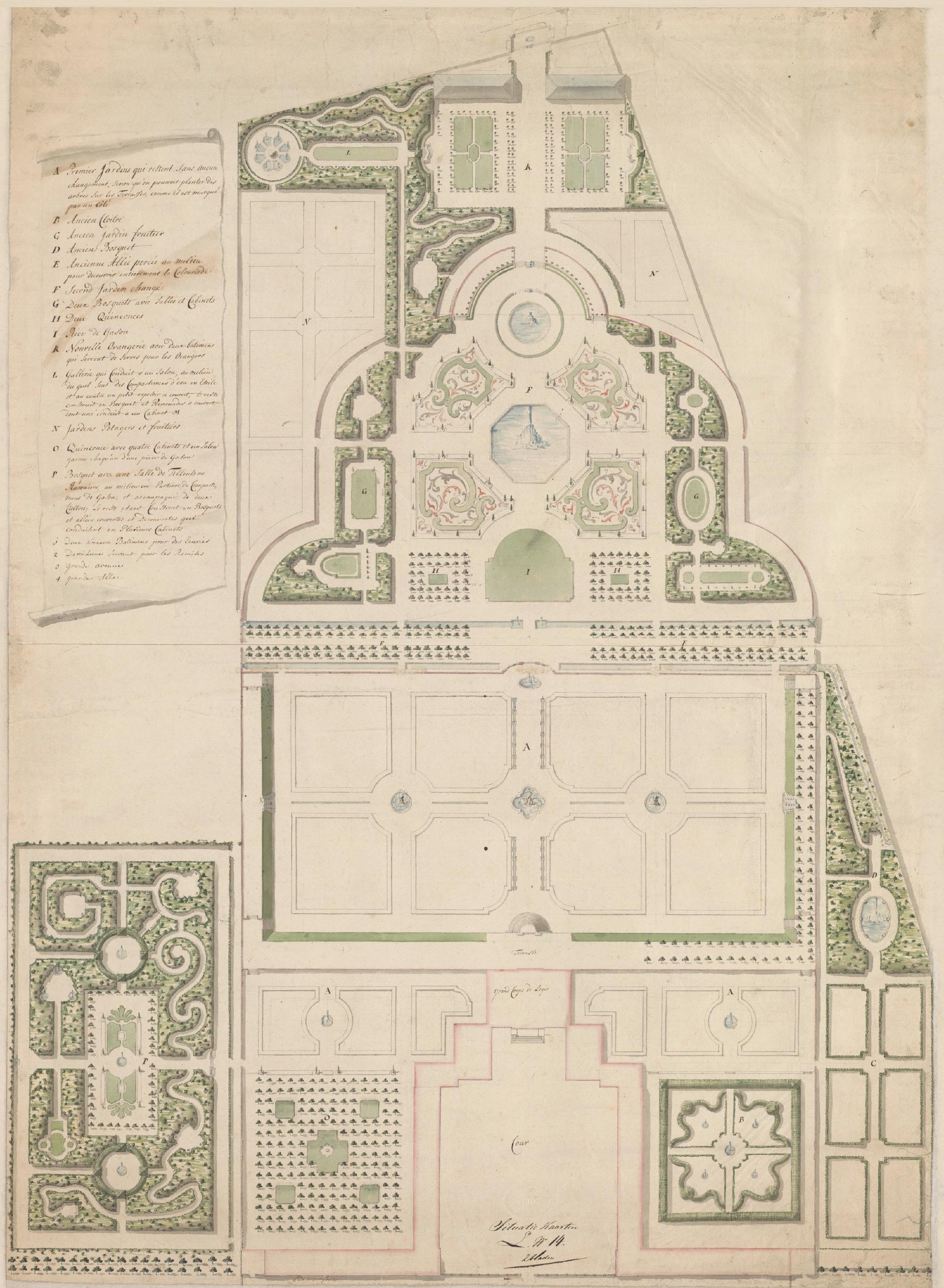


were implemented in gardens across the Netherlands, with the German Johann George Michael (1738-1800) being the leading designer. He was a promising gardener's son turned architect and 'bosch gardenier' (grove or woodland gardener), who had been enticed to the Netherlands by Jacob Boreel Janszoon, owner of the estate Beeckesteyn, near Velsen, and Dutch ambassador in England (1759 and 1761-62), though there is no evidence for which properties he visited there. Boreel Janszoon also sent Michaël to England to study gardens, but again no evidence of this period survives. ${ }^{11}$ Being well qualified meant that Michaël was considered for the job as the next court architect when William V succeeded in 1766 after the regency of his mother Maria Louise van Hessen Kassel. However, instead of Michaël, Philip Willem Schonck (1735-1807), who since 1765 had been in charge of the courtly buildings in Breda, prepared a survey for the gardens of Het Loo in 1767, with his appointment later extended to other princely buildings and gardens. ${ }^{12}$

Schonck's background and training are unknown, but a 1773 proposal for the gardens of Het Loo which envisages a landscape style treatment that erases the formal gardens and incorporates the park in a seamless entity, reveals a sophistication that had not been seen in the Netherlands before (Figure 12.3). It has been suggested that this may have been influenced by the designs of Johann Friedrich Sckell, who worked for William V's brother-in-law in Weilburg, and this could well be the case; the sinuously curvaceous walks are more reminiscent of Germanic than English practice (Figure 12.3).$^{13}$ Various shrubberies surround the palace and project into the park to the west, with the old castle being surrounded by an open grove. It seems that this design was before its time and implemented proposals provide evidence of a more piecemeal approach, which meant that existing garden areas were improved with the type of alterations remaining firmly within continental practice. The 1773 proposals for the menagerie near the old castle included geometric serpentine walks, reminiscent of Batty Langley's earlier models. ${ }^{14}$ In 1775 Schonck designed two pavilions each topped with a two-storey Chinese pagoda, in line with the contemporary fashion for chinoiserie, located either end of the pool of the menagerie. ${ }^{15}$ This suggests more the continental influence of chinoiserie than any Brownian roots.

A 1778 design for the upper garden of Het Loo proposing English lawns and shrubberies reveals how the old structure of the gardens continued to be respected, with the old axes maintained, though Schonck questioned whether this was necessary (Figure 12.4). The area included shrubbery beds intersected by sinuous walks. There were also 'Bouquetten' - graduated beds with perennials and annuals to be surrounded by formal beds which served for the orangery plants in tubs, interspersed with exotic plants. Within the cabinets Chinese seats were proposed. Rather than English or German models, this proposal clearly hints at jardin anglo-chinois designs popularised in Georges-Louis le Rouge's Détails des nouveaux jardins a la mode (Paris, 1776). It was another three years before the design was finally revised, this time disposing of the historic cross-axis both simplifying and uniting the design, concentrating on shrubbery beds only, filled in a graduated manner with so-called 'Engelsch hout', English woody plants - a mixture of native and exotic shrubs. ${ }^{16}$ All ornamentation included in the earlier proposal had been eliminated in the scheme for this area in $1781,{ }^{17}$ but later additions to the park included the rustic Willemstempel (William's temple) in gothic style in 1786, positioned in the centre of one of the groves to the west of the old castle. ${ }^{18}$

11 Oldenburger-Ebbers, C. S. (1991). De tuinarchitectuur van Johann Georg Michaël (1738-1800). Bulletin KNOB, 90(3), 73-79.

${ }_{12}$ Tromp, H. M. J. (2012). De Nederlandse Landschapsstijl (p. 200).

${ }^{13}$ Tromp, H. M. J. (2012). De Nederlandse Landschapsstijl (p. 200); see also Woudstra, J. (2002) 'The Sckell family in England (1770-1830)', Die Gartenkunst, 14(2), 211-220.

14 Langley, B. (1728). New principles of gardening.

${ }^{15}$ Van Everdingen-Meyer, L. R. M. (1974). De Lusthof Het Loo van de Koning-Stadhouder Willem III en zijn Gemalin Mary II Stuart (p. 70). The Hague: Staatsuitgeverij.

${ }^{16}$ Woudstra, J. (2013). From bosquet a l'angloise to jardin a l'angloise.

${ }_{17}$ A survey of 1806 reveals that this design was implemented: Collectie Rijksarchief den Haag, RL2676, Maximiliaan de Man, 'Kaart van het Koninglijk Loo', 1806.

18 Tromp, H. M. J. (2012). De Nederlandse Landschapsstijl (p. 206).

Figure 12.2 (page 168): Unexecuted proposals for the gardens at Het Loo Palace, Pieter de Swart, c. 1748, which introduced new groves within the walled gardens and converted the king's wilderness to a slightly more irregular layout, incorporating serpentine walks after the English manner. Source: Nationaal Archief, Den Haag, the Netherlands, no. 4.OSK L14a. Public Domain. 


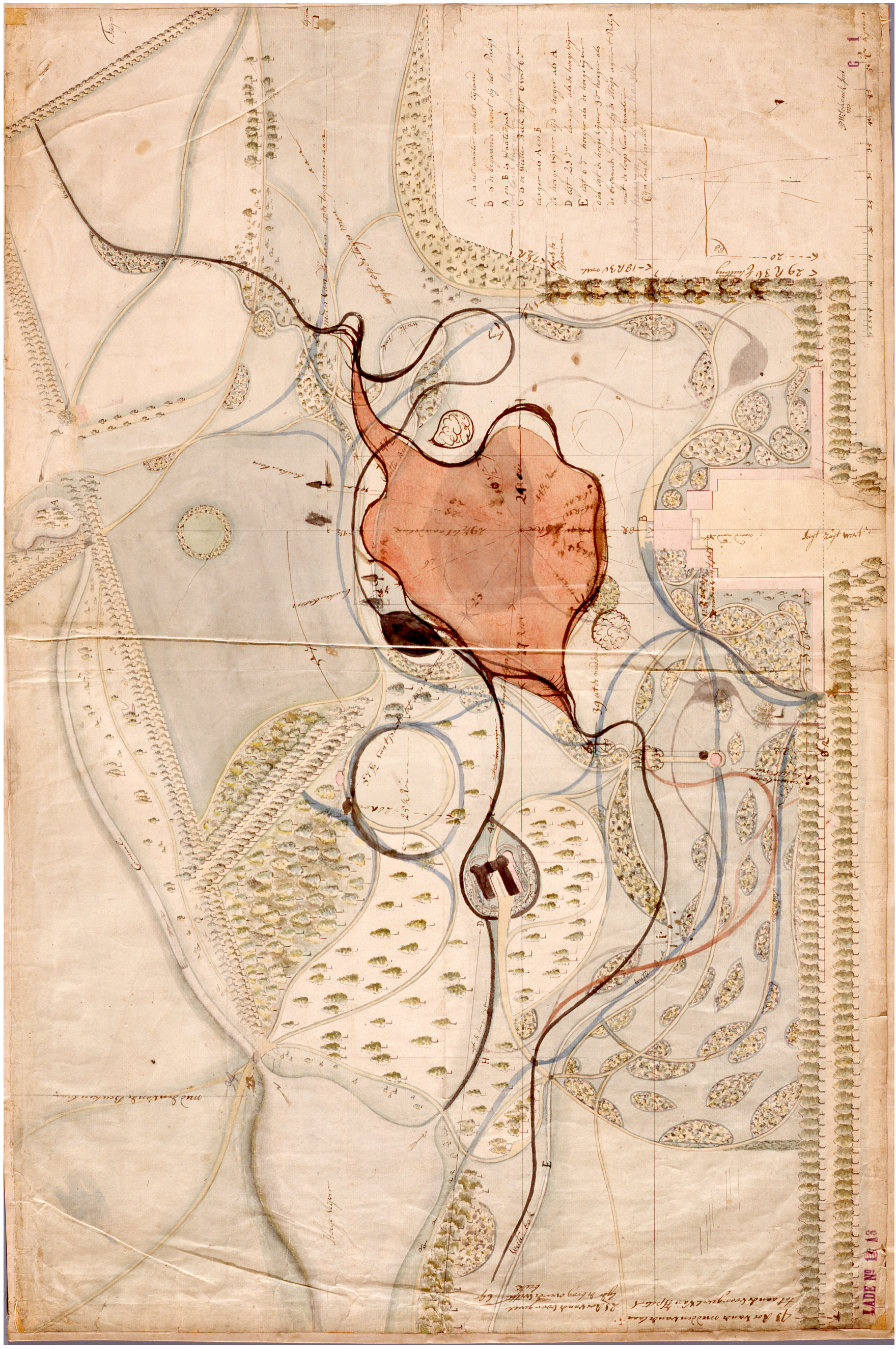

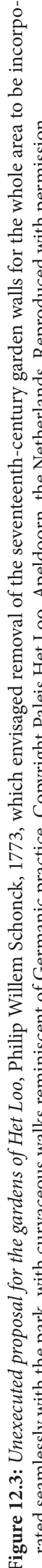



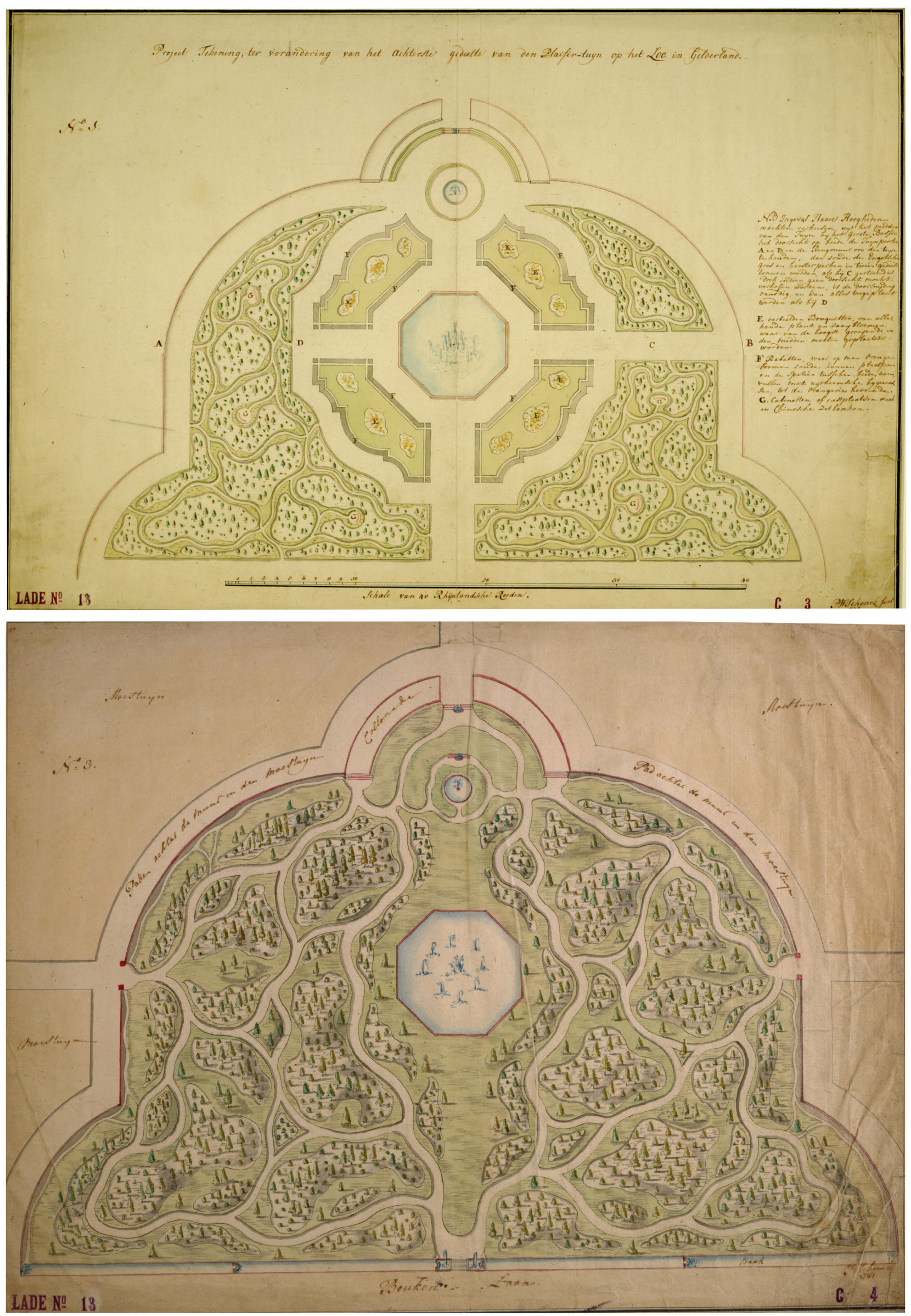

Figure 12.4: Two design proposals by Schonck for the upper garden within the walled area of the garden of Het Loo which consisted primarily of shrubbery beds with 'Engelsch hout', a mixture of native and exotic woody plants arranged in a graduated manner. Above: an initial design, 1778, that retains formal elements and introduces Chinese seats. Below: a simpler design, 1781, dominated by shrubbery retaining the central axis and which was implemented. Copyright Paleis Het Loo, Apeldoorn, the Netherlands. Reproduced with permission. 
The simplified design may have been in response to the increasing criticism of such English gardens filled with exotic buildings and informal planting. Avondtydkortingen, a translation from the French of a series of moral narratives for the youth by Mrs de Genlis, contains a satiric description of such an English garden and its owner:

[A]n English garden, that is to say, that no tree is being pruned here; that in the low narrow alleys the branches scratch your face, and mess up your hair-style; that thistles and thorns grow freely; that there are two or three hills that are referred to as mountains; that there is a pile of building rubble in a corner that symbolises a ruin; and that there is a derelict hut that is untidy and disgusting. Several small wooden bridges cross a green dirty ditch that carries the name of river. So that, if there were only a rock, a temple and a grave tomb, this garden would have contained all the paraphernalia, that would be impossible not to include in a tasteful and well-judged English garden. Also it cannot fail, or this admirable estate, the masterpiece of the inventive spirit of its owner, must considerably have increased his [the owner's] natural conceitedness. He also knows how to serve with confidence all the advantages that coincide with the spirit of an English garden. He argues against all straight avenues, all sorts of harmony, flowerbeds, clipped box plants, and star shaped groves, and repeated these outdated and exhausted remarks already more than ten years, which he, with well-intended attitude presents one thing or another as something innovative, while he imagines that everyone is bound to admire his fine taste and extraordinary inventiveness. ${ }^{19}$

It is clear that this was not the Brownian English garden but appeared to be in tune with the work of his competitor William Chambers, who had published Designs for Chinese Buildings (London, 1757) with both an English and French text and his Dissertation on Oriental Gardening (London, 1772) translated into French and German in 1775. These works appear to have added to the confusion about the origin of English groves and gardens, and whether they were in fact Anglo-Chinese. Contemporary Dutch sources remained largely ignorant of the notion of the Brownian garden. For example, while there were plentiful sources that provided both practical information and a new philosophical attitude towards nature, until 1802 there were no practical native works that advocated the new Brownian style. That year saw the publication of two companion volumes, Depictions of the Most Beautiful, Most Exotic Trees and Shrubs that Can Be Planted and Grown for the Ornamentation of English Groves and Gardens, by Johan Carl Krauss, and Magazine of Garden Ornaments, by garden architect Gijsbert van Laar. Krauss noted recent changes in the attitude towards nature and the difficulties of copying nature and uniting plants from the East and West Indies with those of Europe. ${ }^{20}$ Van Laar reiterated the belief that the English had learned the latest developments in gardening from the Chinese and this had been applied in the parks of the rich, who had stolen large tracts of land from agriculture. While such land-take would not be feasible in the Netherlands, he argued, it was possible to do this on smaller estates, where these methods help to make them appear larger than they really are. ${ }^{21}$

These remarks on the smaller size of estates should be seen within the context of the French occupation of the Netherlands, during which William V was exiled to Hampton Court in England, and the founding of the Batavian Republic in 1795, which made the Netherlands a vassal state of France. As a result of the occupation the economy was depressed and wealth, and the size of any property, was greatly compromised. Various assets of the former stadholder were sent to Paris, including the menagerie of Het Loo. ${ }^{22}$ When Napoleon Bonaparte created the Kingdom of Holland in 1806, in order to provide his third brother Louis Napoleon Bonaparte with a position, it was also intended to curtail regional independence. However, instead of being a mere prefect, Louis Bonaparte took his responsibilities seriously and represented the country honourably. Problems occurred in 1809, when he was unable to defend the country from the English army without French aid, as a result of which he was exiled in 1810 and the country reverted to the status of a French imperial province. As king, Louis Bonaparte had led an itinerant existence, while taking over royal properties and improving the various gardens by the German born Johann David Zocher senior (1763-1817), who was appointed as court architect

${ }^{19}$ de Genlis, Mrs (1788). Kasteel of Zedelyke Verhalen (pp. 14-15). The Hague.

${ }^{20}$ Krauss, J. C. (1802). Afbeeldingen der Fraaiste, Meest Uitheemsche Boomen en Heesters die tot Versiering van Engelsche Bosschen en Tuinen op onze Grond, kunnen Geplant en Gekweekt worden (pp. ii-viii). Amsterdam.

21 Van Laar, G. (1802). Magasijn van Tuin-sieraden (p. ii). Zaltbommel.

${ }^{22}$ Nieuwe Algemene Konst- en Letter-bode, voor Meer- en Min-geoefenden 5/156 (1796), 201-202. 
in $1807 .{ }^{23}$ On arriving in the country Zocher had initially been employed by Michaël. Zocher later married Michaël's daughter and set up independently as an architect and garden designer. His appointment for Louis Bonaparte included work at Huis ten Bosch in 1807, Soestdijk and Amelisweerd in 1808, the Palace at Utrecht, and Welgelegen at Haarlem in 1809, though he was clearly too busy to tackle further work at Het Loo, for which another designer had to be sought. ${ }^{24}$

Het Loo Palace became one of Bonaparte's country residences, ${ }^{25}$ and a survey by M. J. de Man of 1806 established the existing situation in advance of any proposed changes. Schonck's 1773 design that proposed a holistic transformation was revived and appears to have been used as a basis for some initial sketches. This was done by the French architect Alexander Dufour (1760-1835), who in 1799 had been embroiled in a debate over the competition of a naval monument proposed in Greenwich, England, ${ }^{26}$ and later (from 1810 to 1832) worked at Versailles as architect for Louis XVIII. The architect for the palace was Jean-Thomas Thibault (1757-1826), who additionally was a well-known landscape painter and during the empire also restored Huis ten Bosch, The Hague, and turned Amsterdam town hall into a palace. ${ }^{27}$ While Louis Bonaparte was greatly involved with the gardens, both of these French architects collaborated with Johan Philip Posth (1763-1831), who appears to have taken charge of the work on both buildings and gardens, c. $1808 .{ }^{28}$ Posth was well experienced and worked in the province of Gelderland between 1791 and 1803, completing various gardens, including those at Verwolde, Ruurlo, Bingerden, and Kell. ${ }^{29}$ Dufour's design for Het Loo finally removed the formal gardens and with extensive earth moving and planting created an informal layout that placed the palace at its centre, whilst the grounds were greatly extended by land acquisition. Interconnecting sinuous paths, which suggest a continental rather than English inspiration, created a multiplicity of walks. These were enhanced by judiciously positioned shrubberies which disguised the formality of the woodland vegetation that was largely retained. There were various shrubberies in oval or rounded beds that provided a variety of long and short views and focal points. Notably, no lake was created and nearby fish ponds were left in their formal arrangement. This has been said to be because Louis Bonaparte did not like water near his residence, but more likely it was necessary in order to save costs, particularly as it would have required the removal of the foundations of the formal garden. ${ }^{30}$ Instead of a lake, therefore, there was an extensive lawn, or pelouse. The new arrangement was shown on an 1812 survey by Pieter Broekhoven (1757-1834), master gardener at Het Loo, and clearly reveals the French roots of the design (Figure 12.5).

The loss of the formal gardens was lamented by William VI when he returned to the Netherlands in 1814 as sovereign prince. He became King William I of the United Kingdom of the Netherlands a year later and within a few years he was apparently reconciled to the new layout and embarked on a series of gradual improvements that characterised the remainder of the nineteenth century. Changes included the transformation of the fish ponds to an informal bathing pond in 1818-19, with similar treatments to other fish ponds in succeeding years. Other additions included an ornamental farm built for Princess Marianne in 1825 and a rustic pavilion, Bylandt's Rest, named after the superintendent of the royal palaces after he had been found asleep there. A series of views produced in 1837 by Friedrich Textor, the 'Plantagie Meester', or head forester in charge of the grounds, recorded the developments in the park and reveal an emphasis on enclosed spaces, rather than wide Brownian-type views. ${ }^{31}$ It reveals a preference for forestry, rather than providing for grazing in extensive open Brownian-type parkland (Figure 12.6).

${ }^{23}$ Dieltjes, E. Zocher, J. D. In Biografisch Woordenboek van Nederland. Available at http://resources.huygens.knaw.nl/bwn1780-1830 /lemmata/data/Zocher, accessed 12 November 2013.

24 Oldenburger- Ebbers, C. S., Backer, A. M. \& Blok, E. (1995). Gids voor de Nederlandse Tuin- en Landschapsarchitectuur (pp. 476-477).

25 Elzenga, E. (1992). Het Witte Loo: Van Lodewijk Napoleon tot Wilhelmina 1806-1962 (p. 9). Apeldoorn: Rijksmuseum Paleis Het Loo.

${ }^{26}$ He published: Dufour, A. (1800). A letter to the nobility and gentry composing the committee for raising the naval pillar, or monument, under the patronage of His Royal Highness the Duke of Clarence; in answer to the letter of Mr John Flaxman, sculptor, to the committee, on that subject. London.

${ }_{27}$ Curl, J. S. (Ed.). (2006). A dictionary of architecture and landscape architecture (p. 773). Oxford: Oxford University Press.

${ }^{28}$ Alexander Dufour, 'Plan general des grand et petit parcs du Palais du Loo', Coll. Archives Nationales, Paris, NII, Zuyderzee' No 1, $191 \times 96$.

29 van der Does, A. (2016). Aangelegd door zekeren Posth. Jaarboek Achterhoek en Liemers, 39, 41-54.

${ }^{30}$ Tromp, H. M. J. (1992). Het park van Het Loo: het landschapspark als memorietafel. In E. Elzenga (Ed.), Het Witte Loo: Van Lodewijk Napoleon tot Wilhelmina 1806-1962 (pp. 15-32, [18-19]). Apeldoorn: Rijksmuseum Paleis Het Loo.

31 Textor, F. (1837). Twaalf Gezichten in het Park Het Loo: Naar de natuur getekend en opgedragen aan Zijne Excellentie den Heere Opperintendant van Zijner Majesteits Paleizen, enz, enz, J.C. Grave van Bylandt. Apeldoorn. 


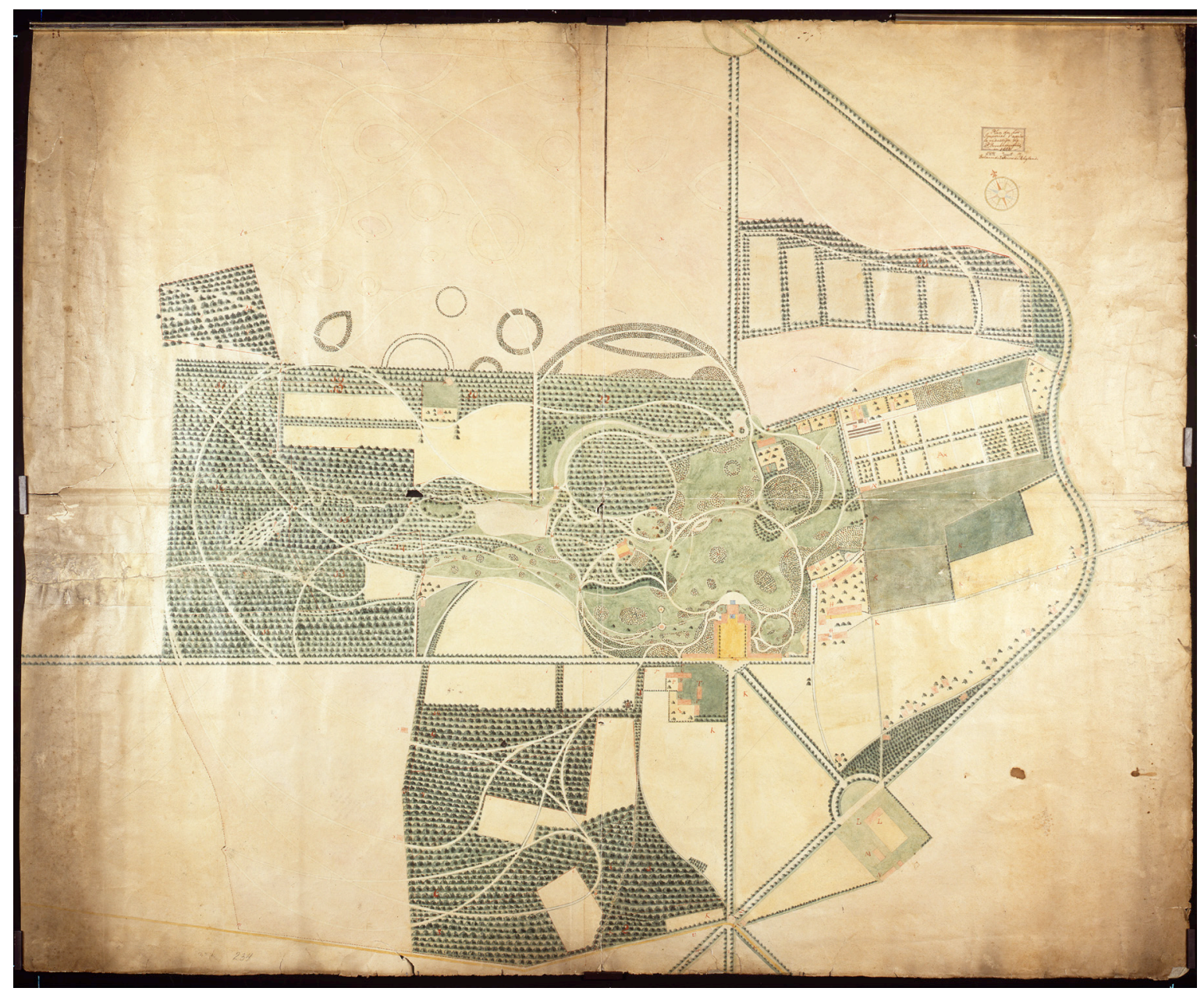

Figure 12.5: Survey, Pieter Broekhoven, 1812. When Louis Bonaparte became king the French architect Alexander Dufour made proposals to eliminate the old formal gardens with an extensive unifying layout, which was executed by Johan Philip Posth. Dufour appears to have made use of Schonck's 1773 proposals for some initial sketches (Figure 12.3). Nationaal Archief, Den Haag, the Netherlands, 4.VTHR 467. Public Domain.

\section{The Notion of the Landscape Garden and Reception of Brown}

The difference between the Brownian approach and general Dutch desire for woodland rather than open parks is perhaps best illustrated by a 1793 publication on the Haarlemmer Hout, the Haarlem Wood, which had been replanted in a regular manner in 1755, with Michaël adding serpentine walks in $1788 .{ }^{32}$ In his book of 1793 Adriaan Loosjes lamented the stiffness of the Le Nôtre style, which had penetrated the 'pleasure groves' in the Netherlands, and he praised the 'great Hirschfeld' and the 'immortal Kent' for providing another direction, in which nature in its prime should be the only model for Dutch woods/groves and gardens. ${ }^{33}$ Christian Cay Hirschfeld had published a five-volume work, Theorie der Gartenkunst (1779-82), which had become a standard work, available in both French and German. Whilst it included references to Bridgeman and Kent, Brown was only mentioned once, and then in a very general sense, even though some of the landscapes he designed were included, such as Alnwick, Luton Hoo, Nuneham, and Worksop. ${ }^{34}$

${ }^{32}$ Oldenburger- Ebbers, C. S., Backer, A. M. \& Blok, E. (1995). Gids voor de Nederlandse Tuin- en Landschapsarchitectuur (pp. 180-181).

33 Loosjes, A. (1793). Het Hout of Boschgedachten in zes Bespiegelingen (pp. 20-21). Haarlem.

${ }^{34}$ Hirschfeld, C. C. (1779-82). Theorie der Gartenkunst (5 Vols; Vol. 4, p. 8, 'Brown und andre vortreffliche Gartenkünstler...'). Leipzig. 


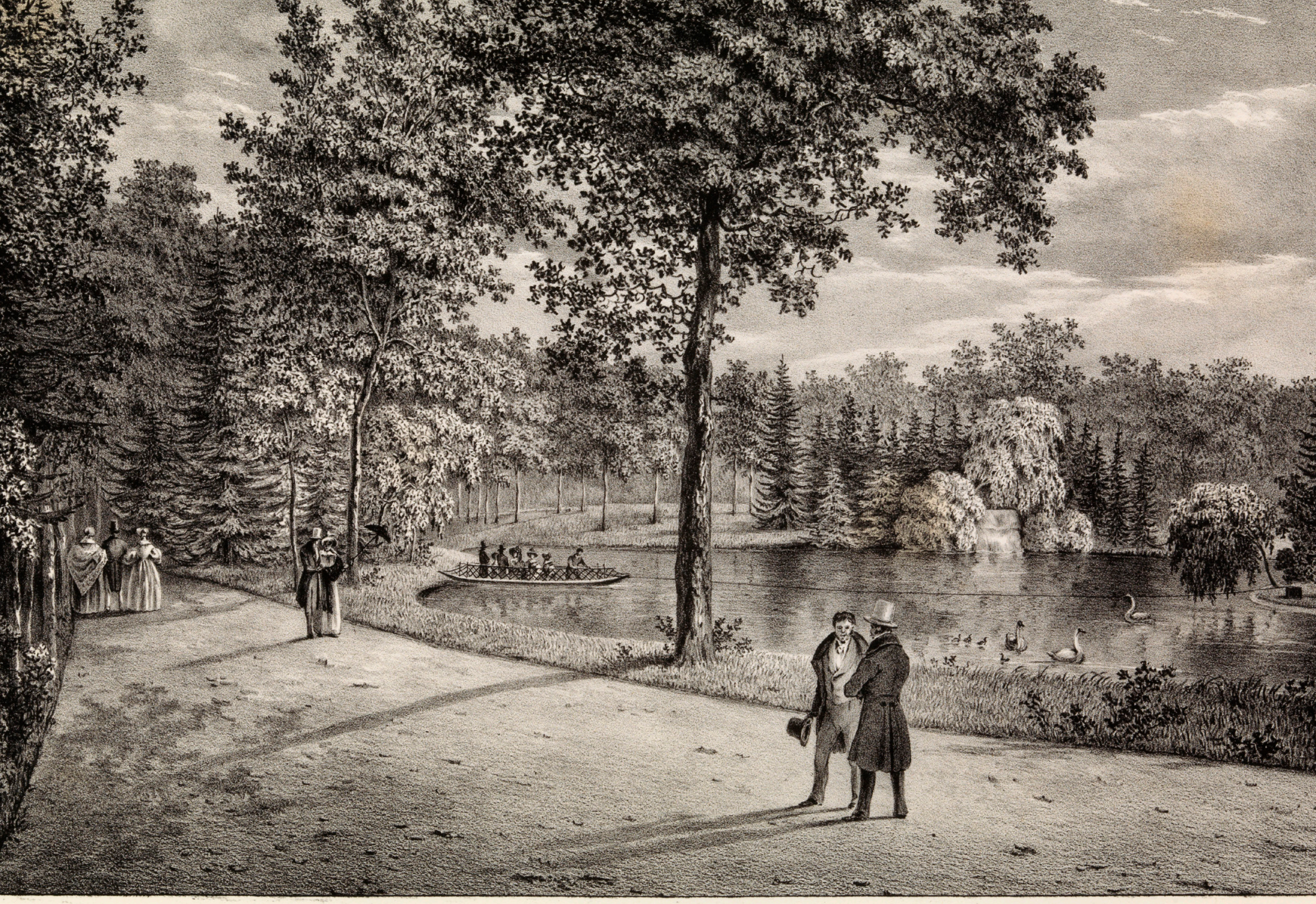

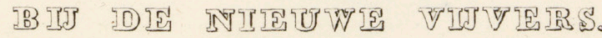

Figure 12.6: By de nieuwe vyvers, Friedrich Textor, 1837. A series of views made of the new garden areas at Het Loo by Friedrich Textor, the head forester, reveals an emphasis on enclosed spaces, rather than wide views associated with Brown. Copyright Paleis Het Loo, Apeldoorn, the Netherlands. Reproduced with permission.

German and French were popular languages with the Dutch elite, which would read both Goethe and Rousseau in their original languages but would be reluctant to read in English, despite the fact that some English literature was eagerly read in translation. James Thomson's The Seasons (1726-30), which reflected on countryside, nature, and landscape, was variously translated, and Thomas Whately's Observations on Modern Gardening (1770), which included descriptions of places designed by Brown (though not named) such as Moor Park, Claremont, Wotton, and Stowe, was translated into both German and French. Horace Walpole's Essay on Gardening (1785), which promoted William Kent as the 'inventor of the new style' of gardening, was translated into French. The informed position on Kent in Hirschfeld could only have been derived from Walpole. Remarkably, while Walpole mentioned Brown, he did not expand on his contribution to gardening, reserving him 'for some abler pen' instead. ${ }^{35}$

This 'abler pen' came a decade later in the guise of Humphry Repton, who in his Sketches and Hints on Landscape Gardening (London, 1795) commenced with an acknowledgement of Brown's contribution to what

${ }_{35}$ Walpole, H., History of the modern taste in gardening. In W. Marshall (1803), On planting and rural ornament: A practical treatise (Vol. 1, pp. 197-251 [223, 242]). London. 
he referred to for the first time as 'landscape gardening. ${ }^{36}$ As a thirteen-year-old, Repton had been sent from Norwich to study in the Netherlands, first for a year in Woudrichem and then for two years in Rotterdam with Zachary Hope (1711-70), the ship owner, in order to learn the business and promote trade relations. ${ }^{37}$ After Repton abandoned his efforts to be a merchant and set up as a landscape gardener, he gained particular fame for his publications, which were reviewed in the Netherlands, where in 1796 it was noted that the art of garden design had come to occupy a distinct category in British literature. Loosjes, the reviewer, revealed a thorough awareness of the contemporary developments in England, referring to the Picturesque debate with William Gilpin, Richard Payne Knight, and Uvedale Price and their complaint of the Brownian manner, the 'system of clumping and belting. How Repton had become embroiled in this debate was also explained. Loosjes considered the latter's Sketches as an indispensable source in order to comprehend the latest developments in garden art with its new notions regarding the use of perpendicular and horizontal lines, and the revival of avenues. Repton's book was considered well worth translating, Loosjes thought, but this had to be done 'not by a bungler, but by someone who had been to England and had studied the history of the art, particularly the layout of Brown at Blenheim, the Leasowes and Repton's work at Welbeck'. It was clear that, though Brown's work was considered outstanding, he was not viewed as pre-eminent above all others. Other sources which Loosjes considered important in his review included William Marshall's Planting and Rural Ornament (London, 1796) and George Mason's Essay on Design in Gardening (London, 1768). ${ }^{38}$

The trend to recognise Brown's contribution, but to do so alongside his contemporaries, is apparent in a Dutch translation from a French account of a Historic and Literary Journey to England and Scotland by Amédée Pichot, originally published in 1825 . It suggests that there was a growing recognition of Brown alongside Kent, with both referred to as landscape architects, 'architects-payisagistes' or 'landschaps-bouwkundigen', in relation to their work at Claremont. ${ }^{39}$ However, a concise review of garden art in the mid-nineteenth century by the clergyman T. F. Uilkens praised 'ingenious Kent' but did not refer to Brown, which reveals that his position in garden history was still not properly acknowledged. Uilkens, who promoted agricultural improvement and mainly worked in the northern provinces, perhaps had a slightly restricted view of the world of garden design. He considered Lucas Pieters Roodbaard (1782-1851) to be the practitioner most adept at English style gardens. ${ }^{40}$ While this was true, particularly in Friesland, it was the various generations of the Zocher family that continued to be the most influential garden designers in the other provinces of the country. Jan David Zocher junior (1791-1870), who had studied at the École des Beaux-Arts in Paris, became a well-known architect on his return to the Netherlands and became a member of the Royal Institute of British Architects in 1828, suggesting not only a strong cultural affiliation with England but also extensive knowledge of contemporary design of buildings and landscape gardens. While this may have included examples of Brownian parks, it is more likely that this would have been instances by Repton. A rare instance of a Dutch designer in England was Willem Arentz, a pupil of Michaël, who spent two years in England before returning to the province of Holland and advertising himself in 1793 as surveyor and designer of 'English gardens and estates'. Arentz apparently failed to capitalise on this experience and training since there are no known works by him, suggesting that there was no great demand for Brownian landscapes. ${ }^{41}$ Garden designer and nurseryman Hendrik van Lunteren (1780-1848) also reputedly spent a year in England, 'to increase his scientific knowledge of horticulture, and to shape his taste in laying out country seats', but, since his subsequent schemes remained in a continental style, his experience also suggests that the Brownian style failed to establish itself in the Netherlands. ${ }^{42}$

${ }^{36}$ Loudon, J. C. (1839). The landscape gardening and landscape architecture of the late Humphry Repton (p. 30). London.

37 Loudon, J. C. (1839). The landscape gardening and landscape architecture of the late Humphry Repton (pp. 8-9); Finch, J. (2019). Humphry Repton: Domesticity and Design. Garden History, 47(Suppl. 1), 24-38.

38 Loosjes, A. Engelse letterkunde: vierde beschouwing. In Nieuwe Algemene Konst-en Letter-bode, voor Meer-en Min-geoefenden 5/143 (1796), pp. 98-100.

39 Pichot, E. (1826). Geschied- en Letterkundige Reis naar Engeland en Schotland, translated by M. Martens (3 Vols, Vol. 1, p. 30). Haarlem.

40 Uilkens, Th. F. (1854). Aanleg van Parken: Bloementuinen (p. 3). Amsterdam: Weiting \& Van der Haart.

${ }^{41}$ Tromp, H. M. J. (2012). De Nederlandse Landschapsstijl (p. 264).

${ }^{42}$ Kramm, C. (1857). De Levens en Werken der Hollandsche en Vlaamsche Kunstschilders, Beeldhouwers, Graveurs en Bouwmeesters van den Vroegsten tot op Onzen Tijd (p. 1023). Amsterdam: Diederichs. 
A more famous example is Repton's son, John Adey Repton (1775-1860), who was reported to have designed two sites in the Netherlands, one near Arnhem and one near Utrecht, during the early-nineteenth century. ${ }^{43}$ This was possibly through connection with the Hope family and may well refer to Sonsbeek and Beverweerd, both owned by the affluent Baron van Heeckeren. Hendrik Jacob Carel Johan van Heeckeren van Enghuizen (1785-1862) married Elisabeth Hope (1794-1860) in 1816, inherited Beverweerd in 1810, and bought Sonsbeek in 1821, the year Repton was reported as being in the Netherlands. ${ }^{44}$ It is clear that, by the midnineteenth century, any Brownian influence or legacy on landscape design in the Netherlands was being mediated through Repton's own idiom.

\section{The Modern Legacy}

The narrative of landscape design constructed in the second half of the nineteenth century and into the twentieth century continued to play down Brown's role. A brief history by the architect F. J. Bremmer written in 1886 praised Kent but criticised Brown's contribution, despite the acknowledged popularity of his work at Blenheim, repeating the Picturesque criticisms of his use of clumps and belts. ${ }^{45}$ Leonard A. Springer (18551940), then perhaps the most representative designer in the English style in the Netherlands, responded by citing the Anglo-Chinese style as the 'landscape style', initiated by William Temple and popularised by Kent, who had finally initiated the landscape style. Chambers, whom he believed had studied in China for a long time, provided the impetus for further development. With this emphasis, Brown's contribution continued to be unacknowledged in favour of nineteenth-century English designers Joseph Paxton and John Gibson, yet his unfamiliarity with the British scene is clear from the additional naming of the civil servant John Fordyce (d. 1809), Surveyor General to H.M. Land Revenue and initiator behind the development of Regent's Park estate, as one of the leading landscape gardeners. So, when Springer concluded that there were three main influences the English school, largely following the tradition of Repton; the French school of Barillet-Deschamps; and the German school of Pückler and Schinkel-Lenné - this was with limited knowledge of Brown's contribution. ${ }^{46}$

Springer recognised that there was a considerable difference in scale between British and Dutch gardens, with the exception of Het Loo, for which he explored the history of the making of the gardens. While his understanding of the development of the English garden there was limited, when he was asked to make alterations it was sufficient for him to assess the special qualities of the site. Queen Wilhelmina succeeded in 1898 and, after her marriage to Prince Hendrik of Mecklenburg-Schwerin in 1901, they decided to make Het Loo their main residence. It needed various changes. In 1907 a large stable block was built to the west of the palace, and a villa to the south-west for the queen's private secretary. This meant that the front of the palace required reorganisation, with Springer designing a patte d'oie planted with avenues to connect the various buildings. ${ }^{47}$ Instead of celebrating this strict formality it was disguised by informal planting along the edges (Figure 12.7). The park was substantially enlarged, almost doubling in size from 350 to 650 hectares, with new walks and associated planting all in an informal style that Springer referred to as 'landscape style'.

\section{The Notion of the Landscape Style}

As one of the most prolific pioneers in garden history, Springer soon popularised the concept of the landscape style, which became a general notion and has since determined the modern narrative on styles. The landscape style has sometimes been treated as a synonym of the romantic style, while others such as C. L. J. Schaum, a teacher at the Boskoop horticultural school, used it as being distinctive. In 1916 Schaum considered that the term 'landscape style' was influenced by painting, whereas the romantic style had a philosophical and poetical basis, although it was recognised that until Repton this was difficult to clearly distinguish.

\footnotetext{
43 'John Adey Repton, Obituary', The Gentleman's Magazine, 210(1861), pp. 107-110 (p. 108).

${ }^{44}$ Geneology online: West-Europese adel. https://www.genealogieonline.nl/en/west-europese-adel/I155265.php, accessed 1 May 2016; Rijksmonumentenregister. https://monumentenregister.cultureelerfgoed.nl/monumenten/528856, accessed 1 May 2016.

${ }^{45}$ Bremmer, F. J. (1886). De geschiedenis der tuinbouwkunst De Opmerker, 21(30), 240.

46 Springer, L. A. (1886). Nog een paar woorden over de geschiedenis der tuinarchitectuur. De Opmerker, 21(35), $279-281$ (p. 281 ).

47 Springer, L. A. (n.d.). Design for forecourt, Het Loo Palace. Apeldoorn: Paleis Het Loo, no. RL4124.
} 


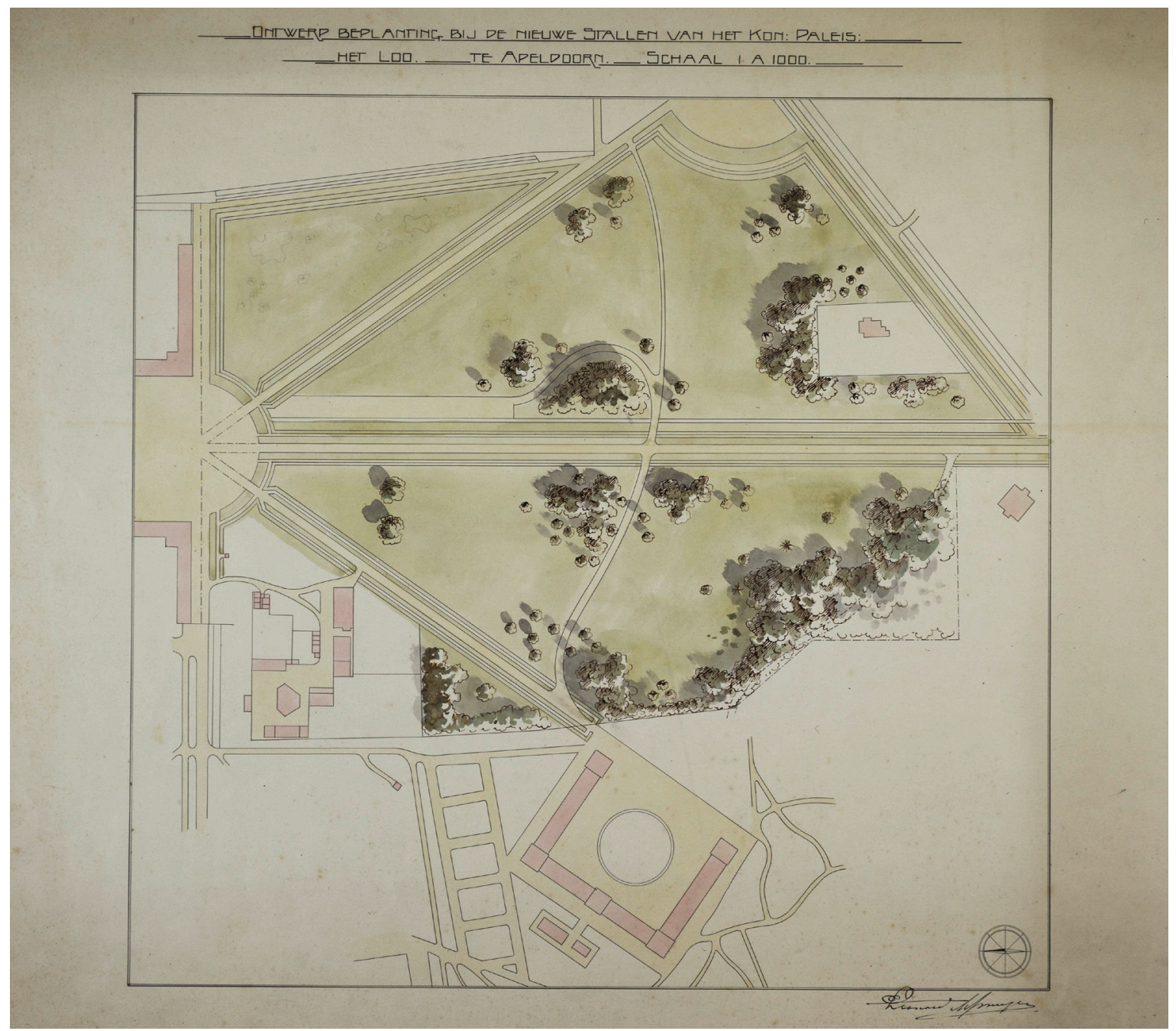

Figure 12.7: In his design for the forecourt of Het Loo in 1907 the leading Dutch garden architect Leonard Springer introduced a patte d'oie of avenues, which shows how the formality of the new avenues was mediated by principles of the landscape style. Note direction of north, as indicated on the plan. Copyright Paleis Het Loo, Apeldoorn, the Netherlands. Reproduced with permission.

Thus, Kent, Brown, Repton, and Pückler-Muskau were considered to have designed landscape gardens, while Chambers, Girardin, Price, and Hirschfeld were representatives of the romantic style. Kent's work at Carlton House, Claremont, and Rousham was well known, but his most important work was at Stowe. Here he met Brown, who became his pupil. Brown's first job was considered to be the digging of the lake at Wakefield Lodge, for the Duke of Grafton, after which 'he soon became the most desirable garden architect of England and was taken into royal service. Being mainly a practitioner with little talent for drawing and painting, 'his gardens have been devised on the same plan with few variations. His prime work was the garden at Blenheim. His gardens generally display only one scene that can be viewed from the house and is bordered by a broad road in arbitrary curving alignment and guided by groups of trees and shrubs that provide little shade. Here and there, mainly against the wall, there are seats and pavilions. A garden like this, as can easily be understood, offered too little variation, so that it soon became necessary to continue a step further. It shows how as the historic narrative evolved and sites became better known Brown's contribution was more fully recognised. However, while Schaum believed that Shenstone, Whately, and Gilpin provided new directions, and Brown was clearly talented, though not in drawing and painting, it was Repton who 'provided new rules that remain valid to the present day. ${ }^{48}$ Thus it is clear that the Picturesque critique by Knight and Price, continued to affect Brown's reputation.

${ }^{48}$ Schaum, C. L. J. (1916). Geschiedenis der Tuinkunst (pp. 119-121). Zwolle: Tjeenk Willink. 
Springer was still able to ignore Brown when, in 1936, he discussed Kent and the genesis of the landscape style. He argued that Repton's ideas 'suppressed those of his predecessors' and his design principles and those of his allies were maintained well into the nineteenth century. ${ }^{49}$ Thus, Brown's principles of design went unnoticed, partly because they were never properly recorded. It was only after the publication of Dorothy Stroud's book in 1950 that Brown was included more generally in Dutch historic narratives, as part of a post-war revival of all things English..$^{50}$

The 1974 edition of Tuinen [Gardens], the standard work for landscape architecture education, maintained this division of the romantic versus the landscape style, with Kent and Brown's work included in the latter. The modernist criticism launched on their work was that despite theorising on plant grouping there had been no consideration of the spaces created. The landscape style was believed to have been developed from and reflected the English countryside, particularly that along the Thames with its meanders and cut-offs. This was evident in landscape parks in, for example, the shape of the bodies of water, which were reminiscent of a former meander or cut-off in a floodplain, with elongated islands on the inner bend. Lawns would be sculpted like a floodplain lowered in the middle with trees on raised positions; the plant selection would favour deciduous woody plants, with the evergreens, such as holly and box, sourced from ancient woodland. The form of the spaces represented that of pastures in river valleys, which contained some informally positioned trees and informal groups of trees and they were enclosed by woodland edges. As a result of this composition there are large contrasts between the open spaces and the enclosing dense masses of trees. ${ }^{51}$ This reinterpretation of the Brownian landscape garden into the predominant phyto-geographical and ecological narrative of post-war reconstruction reveals how the lack of information on Brown's theory ultimately led to the desire to explain it by the concept of the 'landscape style, a name which it had received first a century after it had been conceived.

\section{Conclusion}

This exploration of the notion of the Brownian influence in the Netherlands is revealing in that it shows that Brown was neither a source of inspiration for landscape design nor a feature in its historiography. His position was long determined by the negative Picturesque criticism levied posthumously on his work, which was repeated by successive commentators into the late-nineteenth and twentieth centuries. Remarkably, it was Kent and Repton who were hailed as the heroes of the 'English garden', and history has been rewritten variously to what ultimately became an 'English landscape garden' narrative. This meant that earlier trends were reinterpreted as part of this narrative, with the introduction of English-inspired graduated shrub planting into woods or groves with serpentine walks, which had initially occurred in England during the first decade of the eighteenth century but only became more commonplace in the Netherlands after the Dutch translation of Miller's Dictionary in 1745. These types of woods were gradually varied in planting style, or opened up to conform to later trends, often with the addition of architectural features in various exotic styles. The term 'early landscape style' is now generally used in the Netherlands to express the eighteenth-century developments, while the 'late landscape style' expresses the nineteenth-century developments.

The instance of the gardens of Het Loo Palace reveals the way these early designs evolved, and that in their conception they had little to do with the notion of a landscape style, but that any ideas involving newer concepts of nature could be easily incorporated through management of vegetation. The new ideas did not emerge directly from England, however, but were mediated through German and French writers and designers. This is evident particularly in how gardens were designed, with a continental style emerging with an emphasis on the experience of walking with wide curvaceous paths that merged into one another, and changing views contrived through strategically positioned planting. In England, Brownian parks were generally at a larger scale, and therefore more open, with a wider range of activities and uses.

It was the garden architect Leonard Springer who in the second half of the nineteenth century consistently adapted the Reptonian concept of the 'landscape garden' to describe what had previously been referred to as the 'English garden. He also confirmed Repton's dominance as the key English influence. This changed in the

\footnotetext{
${ }^{49}$ Springer, L. A. (1936). Bibliographisch Overzicht van Geschriften, Boek- en Plaatwerken op het Gebied der Tuinkunst (pp. 51, 55, 69). Wageningen: Veenman.

50 Stroud, D. (1950). Capability Brown.

${ }^{51}$ Van Alff, J. P., Galjaard, B. J., van Koolwijk, J. H. R. \& Schipper, J. J. (Eds.) (1974). Pannekoek \& Schipper, Tuinen: Tuin-park- landschap (pp. 47-52). Amsterdam, Antwerpen: Kosmos.
} 
aftermath of the Second World War, when the first monograph on Brown was published that positioned him as one of the great landscape designers. In the post-war era, during which native and natural values in landscapes were highly esteemed in the Netherlands, a meandering Thames as the prototype for the English landscape park or garden fitted in well as an example for the transformation of landscape and provided a welcome modern idiom. Thus, Brown was described as a re-interpreter of the English landscape, and he became an exemplar for modern landscape designers in the Netherlands. This chapter reveals that though the Dutch had not really valued him before, a full re-evaluation was finally accomplished in the twentieth century.

\section{Select Bibliography}

A select bibliography is available at the end of this volume, or at: https://doi.org/10.22599/CapabilityBrown.o. 